\title{
NGF Rescues Substance P Expression but not Neurofilament or Tubulin Gene Expression in Axotomized Sensory Neurons
}

\author{
Johnson Wong and Monica M. Oblinger \\ Department of Cell Biology and Anatomy, The Chicago Medical School, North Chicago, Illinois 60064
}

A reduction in the supply of retrogradely transported NGF has been proposed as a possible signal for the axotomy response in dorsal root ganglion (DRG) neurons. Components of the axotomy response that have previously been well characterized in axotomized DRG cells include changes in cytoskeletal gene expression and changes in the expression of neurotransmitters/neuromodulators such as substance $P$. In this study, we examined the role of NGF in the axotomy response by examining protein synthesis and $\mathrm{mRNA}$ levels of the low-MW neurofilament protein (NF-L) and $\beta$-tubulin in DRG cells at 1,7 , and $12 \mathrm{~d}$ after axotomy with and without continuous administration of exogenous NGF. We also examined substance $P$ levels in the DRG by immunocytochemistry under the same experimental conditions. Sciatic nerves of adult male rats were unilaterally transected at the midthigh level, and the proximal nerve stumps were placed into Silastic tubes connected to osmotic minipumps that were filled with biologically active NGF. NGF (0.5 $\mathrm{mg} / \mathrm{ml}$ in saline) was continuously infused $(0.5 \mu \mathrm{l} / \mathrm{hr})$ onto the proximal stumps of transected sciatic nerves for 1-12 d. Control animals were prepared in an identical fashion except that the nerves were treated with saline alone. At death, DRGs were removed from the animals; the L4 experimental DRGs (axotomized) and contralateral L4 DRGs (uninjured) were used immediately for protein synthesis experiments, while the experimental and contralateral L5 DRGs were fixed in $4 \%$ paraformaldehyde and subsequently used for in situ hybridization and immunocytochemistry. From another set of experimental animals, the L4 and L5 DRGs were harvested and used for total RNA isolation and RNA blotting experiments. Immunocytochemical studies using a polyclonal antibody to substance $P$ showed that the immunodetectable levels of this peptide decreased to undetectable levels in DRG neurons after axotomy and saline administration. However, in axotomized neurons treated with NGF, the level of immunodetectable substance $P$ did not decrease,

\footnotetext{
Received June 7, 1990; revised Sept. 25, 1990; accepted Sept. 28, 1990.

This work was supported by NIH Grant NS-21571 to M.M.O. We thank Ronlang Zheng and Judy Pickett for their excellent technical assistance. We also thank Dr. Linda Parysek and Dr. Robert Goldman for their help in assaying the bioactivity of the NGF, Dr. Nick Cowan for the NF-L cDNA probe, Dr. Steve Farmer for the tubulin cDNA probe, and Dr. Larry Wilkin for providing the substance $P$ antibody.

Correspondence should be addressed to Dr. Monica M. Oblinger, Department of Cell Biology and Anatomy, The Chicago Medical School, 3333 Green Bay Road, North Chicago, IL 60064.

Copyright (c) 1991 Society for Neuroscience $0270-6474 / 91 / 110543-10 \$ 03.00 / 0$
}

but instead, increased over even that present in normal DRG neurons. Pulse labeling of DRGs with ${ }^{35}$ S-methionine: cysteine followed by 2-dimensional (2D) gel electrophoresis and fluorography revealed that the synthesis of neurofilament (NF) proteins was decreased, while that of tubulin was increased, $12 \mathrm{~d}$ after sciatic nerve transection. NGF administration to axotomized neurons did not alter this pattern. Quantitative analysis of in situ hybridizations of DRG neurons and RNA blot analysis with CDNA probes specific for NF-L and $\beta$-tubulin mRNAs showed that NGF treatment of axotomized DRGs did not significantly affect cytoskeletal gene expression at the mRNA level. Robust decreases in NF-L mRNA levels and increases in $\beta$-tubulin mRNA levels were present to a nearly identical extent in both NGF-treated and saline-treated DRG neurons after axotomy. These results indicate that, while administration of exogenous NGF can ameliorate the effects of axotomy on substance P expression, the role of NGF in regulating cytoskeletal gene expression in axotomized adult sensory neurons in vivo is not significant.

NGF is a well-characterized trophic factor important for the development and maintenance of sensory neurons (Levi-Montalcini and Angeletti, 1968; Gorin and Johnson, 1979; Thoenen and Barde, 1980; Johnson et al., 1986). It is now well established that, in developing dorsal root ganglion (DRG) neurons, NGF is an essential survival factor and promotes the survival of neurons that reach appropriate targets. NGF continues to be a source of trophic support to mature DRG neurons even though it is not strictly required by adult sensory cells for survival (Yip et al., 1984; Johnson et al., 1986). NGF is produced by target tissues, internalized at axonal endings, and transported retrogradely to neuronal cell bodies (Claude et al., 1982; Richardson and Riopelle, 1984; Yip and Johnson, 1984).

In the event of an axotomy, the supply of retrogradely transported NGF is interrupted. However, NGF receptors (NGFr) are located all along the peripheral axons of DRG neurons (Richardson and Riopelle, 1984), and Schwann cells in the distal stump of an injured peripheral nerve begin to synthesize NGF, NGF mRNA (Heumann et al., 1987a), and NGFr mRNA after denervation (Heumann et al., 1987b); Taniuchi et al., 1988). Also, evidence exists that DRG neurons can transport NGF via their central branch axons under certain conditions (Khan et al., 1987). Thus, it is likely that peripherally axotomized DRG neurons continue receiving some NGF (but probably greatly reduced amounts) by retrograde transport even in the absence 
of peripheral target connection. The loss of trophic support from target cells has long been speculated to play a role in the neuronal response to axotomy (Lieberman, 1971; Johnson et al., 1986). For DRG neurons, a reduction in the level of the retrograde supply of NGF is a potential factor in the axotomy response.

One of the known effects of NGF in mature DRG neurons is the maintenance of substance $P$ expression. Substance $P$, a member of the tachykinin family, is an undecapeptide that functions as a neurotransmitter/neuromodulator in a subpopulation of DRG neurons, the small nociceptive neurons (Nicoll et al., 1980). NGF has been shown to regulate both the level of substance $P$ and the level of preprotachykinin mRNA, which encodes the substance $P$ precursor in cultured adult DRG cells (Lindsay and Harmar, 1989). In axotomized mature DRG neurons, the levels of substance $P$ and preprotachykinin mRNA have been shown to decrease (Goedert et al., 1981; Bisby and Keen, 1986; Nielsch et al., 1987; Nielsch and Keen, 1988). NGF treatment of axotomized adult DRG neurons has been shown to reverse the axotomy-induced changes in substance P levels (Fitzgerald et al., 1985). Thus, results of a number of studies suggest that NGF is a required effector for the maintenance of steady-state levels of substance $P$ levels in adult DRG cells.

NGF treatment is known to evoke a number of other biochemical changes, such as protein phosphorylation and the induction of expression of a number of genes (Greene and Tischler, 1982; Leonard et al., 1987; Milbrandt, 1987; Lindenbaum et al., 1988; Cho et al., 1989). Cytoskeletal proteins appear to be one of the targets of NGF action. For example, NGF has been shown to upregulate the expression of neurofilament (NF) proteins and NF mRNAs (Lee et al., 1982; Lee, 1985; Lindenbaum et al., 1987, 1988) and to modulate tubulin mRNA levels (Fernyhough and Ishii, 1987) in cultured pheochromocytoma PC12 cells. NGF treatment has also been shown to result in alterations in the stability of microtubules (Black and Greene, 1982; Drubin et al., 1985) and to stimulate certain posttranslational modifications of tubulin (Black and Keyser, 1987). At present, most of the research on NGF effects on the cytoskeleton has been conducted on cultured cells, and very little is known about the effects of NGF on the neuronal cytoskeleton in adult neurons in vivo.

The axotomy paradigm provides a good opportunity to evaluate the role of target-derived factors in cytoskeletal gene expression in neurons in vivo. Significant changes in the expression of neuronal cytoskeletal genes are known to occur in adult DRG neurons that have been axotomized. For example, the mRNA levels of various tubulins are upregulated after axotomy, while those of the NF triplet proteins are downregulated (Hoffman et al., 1987; Wong and Oblinger 1987, 1990a,b; Goldstein et al., 1988; Hoffman and Cleveland, 1988; Oblinger et al., 1989). These changes peak at about $14 \mathrm{~d}$ after axotomy and are also reflected at the level of protein synthesis and axonal transport (Hoffman and Lasek, 1980; Oblinger and Lasek, 1985, 1988; Greenberg and Lasek, 1988). To learn more about the regulation of NF and tubulin expression in DRG cells, and to examine the potential role of NGF in cytoskeletal gene expression in vivo, exogenous $\mathrm{NGF}$ was administered to the proximal stumps of transected rat sciatic nerves, and the pharmacological potential of NGF to ameliorate the effects of axotomy on the cytoskeleton in adult sensory neurons was evaluated. We report our findings that NGF replacement therapy did not reverse the axotomyinduced changes in NF or tubulin gene expression, but did abol- ish the axotomy-induced changes in substance $P$ expression in adult rat DRG neurons.

\section{Materials and Methods}

Isolation and characterization of NGF. The 2.5-S biologically active form of NGF was purified from 200 frozen male mouse submandibular glands (Pel-Freeze) using the rapid procedure described in Mobley et al. (1976). Purified fractions of NGF were dialyzed against $0.9 \%$ saline $(\mathrm{pH}, 7.4)$, concentrated using Centricon 10 filtration units (Amicon Corp.), and filter sterilized (Nalgene). The concentration of the NGF solution was measured by a standard Coomassie dye-binding assay (Bradford, 1976) and then diluted to approximately $0.5 \mathrm{mg} / \mathrm{ml}$. The purity was examined by polyacrylamide gel electrophoresis in the presence of SDS (SDS-PAGE) using a $12 \%$ minigel. The gel was fixed and stained according to Burk et al. (1983). Bioactivity of the NGF was assessed by addition of NGF to cultured PC12 cells and confirming that neurite outgrowth in the cells was induced (Greene and Tischler, 1982). At the end of the experiments, remaining NGF from the osmotic minipumps was assayed by SDS-PAGE.

Animals and surgical procedures. Adult male Sprague-Dawley rats (Harlan Sprague Dawley, Indianapolis, IN) weighing 250-350 gm were used for all experiments. All animal were acquired, cared for, and surgically handled in accordance with the guidelines specified in the $N I H$ Guide for the Care and Use of Laboratory Animals. For surgical procedures, animals were anesthetizcd with a mixture of sodium pentobarbital $(27 \mathrm{mg} / \mathrm{kg}$ ) and chloral hydrate $(128 \mathrm{mg} / \mathrm{kg})$; for scheduled kills, animals were decapitated under ether anesthesia.

The right sciatic nerves of rats were transected at midthigh, and the proximal nerve stumps were immediately placed into $1-\mathrm{cm}$-long cuffs of Silastic tubing that were connected via smaller-diameter polyethylene tubing to osmotic minipumps (Alzet), which were implanted subcutaneously on the back. The cuffs on the nerves were snug but not tight. Before implantation, the osmotic pumps were filled with either NGF $(0.5 \mathrm{mg} / \mathrm{ml})$ or sterile saline and primed by incubation in sterile saline at $37^{\circ} \mathrm{C}$ for $2 \mathrm{hr}$. The entire length of tubing from pump to nerve stump was filled with either NGF or saline at the time when the nerve stumps were placed into the tubing. The pumps delivered $0.5 \mu \mathrm{l} / \mathrm{hr}$ of either NFG $(0.5 \mathrm{mg} / \mathrm{ml})$ or saline in a continuous manner to the proximal nerve stumps.

At 1,7 , and $12 \mathrm{~d}$ after nerve transection and placement of the nerves into the Silastic tubes, rats were decapitated, and the L4 experimental DRGs (axotomized) and contralateral control DRGs (not transected) were removed and immediately used for protein synthesis experiments (see below). Experimental and contralateral L5 DRGs were removed, fixed in 4\% paraformaldehyde for $2 \mathrm{hrs}$, and subsequently processed for in situ hybridization and immunocytochemistry experiments (see below). Four rats at each time point and condition were used for these studies. In addition, a second group of rats, prepared in an identical manner, were killed at 1,7 , and $12 \mathrm{~d}$, and the experimental and contralateral control I. 4 and L5 DRGs were removed and rapidly frozen on dry ice for RNA isolation and RNA blotting experiments (see below). Three rats at each time point and condition were used for the RNA blotting studies.

Immunocytochemistry. Axotomized and contralateral control L5 DRGs from both the NGF- and saline-treatment conditions and normal control L5 DRGs were fixed in 4\% paraformaldehyde for $2 \mathrm{hr}$, rinsed for $4 \mathrm{hr}$ in phosphate-buffered saline (PBS), dehydrated, and embedded in paraffin. Tissue blocks were sectioned at $10 \mu \mathrm{m}$, and the histological sections were mounted on gelatin chrome-alum-subbed slides. Slides were stored at $-20^{\circ} \mathrm{C}$ until used for immunostaining or in situ hybridizations (below). For immunostaining, sections were deparaffinized, hydrated in PBS, and incubated in 4\% normal goat serum (NGS) in PBS for $1 \mathrm{hr}$. This blocking serum was lightly drawn off by suction, and primary antiserum (rabbit polyclonal antibody to substance $\mathrm{P}$; Wilkin et al., 1983) was applied at 1:1000 dilution in PBS with 1\% NGS for $24 \mathrm{hr}$ at $4^{\circ} \mathrm{C}$. The sections were rinsed with PBS and reacted with biotinylated anti-rabbit IgG $(1: 200$ in PBS $)$ at $24^{\circ} \mathrm{C}$ for $1 \mathrm{hr}$. The sections were rinsed with PBS and incubated for $1 \mathrm{hr}$ with Vectastain Elite ABC Reagent (avidin DH/biotinylated HRP H, 1:50 in PBS; supplied with the $\mathrm{ABC}$ Elite kit from Vector Immunocytochemicals). The reaction product was then visualized with $0.05 \%$ diaminobenzidine and $0.02 \%$ $\mathrm{H}_{2} \mathrm{O}_{2}$. Slides were rinsed with water for $1 \mathrm{hr}$, dehydrated, coverslipped with Permount, and examined by light microscopy.

In situ hybridization. Preparation of histological material was as de- 
scribed above for immunocytochemistry. In situ hybridization with ${ }^{35} \mathrm{~S}$ labeled cDNA probes specific for low-MW NF protein (NF-L) and $\beta$-tubulin was performed as previously described (Wong and Oblinger, 1987, 1990a,b). Sections of experimental L5 DRGs (either NGF-treated or saline-treated) at 1-12 d after axotomy and sections of normal controls were hybridized with ${ }^{35} \mathrm{~S}$-labeled NF-L cDNA (Lewis and Cowan, 1985 ) or $\beta$-tubulin cDNA (entire clone RBT1; Bond et al., 1984) and washed to a final stringency of $0.5 \times$ SSC with $5 \mathrm{~mm}$ DTT at room temperature. On Northern blots of total RNA from rat DRG, the NF-L cDNA hybridizes with $2.5-\mathrm{kb}$ and $4-\mathrm{kb}$ mRNAs, and the $\beta$-tubulin cDNA hybridizes with a 1.8-kb mRNA (Wong and Oblinger, 1990a). After hybridization, slides were dipped in Kodak NTB2 emulsion, dried, and incubated in the dark for 2-8 d, and then the autoradiographs were developed. Sections were lightly counterstained with cresyl violet, dehydrated, and coverslipped with Permount.

Using a computer-based image analysis system (MicroComp), the density of silver grains overlying large-sized DRG neurons $\left(>1000 \mu \mathrm{m}^{2}\right)$ was determined as described previously (Wong and Oblinger, 1987, 1990a). Only neurons with apparent nuclei and nucleoli were selected for grain counting. At least 25 large DRG neurons from each ganglion were randomly selected for quantification, and the average grain density from at least 4 ganglia ( 100 or more cells in total) for each time point and condition was determined. For graphical purposes, the mean grain densities over axotomized DRG neurons were plotted as a percentage of those in normal control DRG neurons at the different postaxotomy times. For statistical comparisons, differences in the mean grain densities of experimental versus control DRG neurons and between the NGF-treated and saline-treated DRG neurons were assessed using the Student's $t$ test $(p<0.05)$.

Protein synthesis. For in vitro labeling of newly synthesized proteins, the experimental and paired contralateral L4 DRGs were removed from the animals. The ganglia were desheathed, the ventral and dorsal roots and peripheral nerve branches were trimmed, and a colored string was tied around the short stump of the peripheral nerve branch. A matched pair of experimental and control DRGs (from the same animal) was placed in a small tube containing $500 \mu \mathrm{l}$ of a methionine- and cysteinefree Minimal Essential Media (MEM) made using the Select-Amine Kit (Gibco, Grand Island, NY) and allowed to equilibrate for $20 \mathrm{~min}$ at $37^{\circ} \mathrm{C}$ with bubbling $95 \%$ oxygen. The DRGs were then transferred to $500 \mu \mathrm{l}$ of fresh MEM solution containing $500 \mu \mathrm{Ci}$ of ${ }^{35} \mathrm{~S}$-Trans-label ${ }^{35} \mathrm{~S}$-methionine : cysteine; ICN Radiochemicals, Irvine, CA) for $1 \mathrm{hr}$ at $37{ }^{\circ} \mathrm{C}$ with $95 \%$ oxygen bubbling. Next the ganglia were rinsed with PBS and then homogenized in $0.5 \%$ SDS, $8 \mathrm{~m}$ urea and $2 \% \beta$-mercaptoethanol (SUB) and centrifuged for $10 \mathrm{~min}$ at $17,000 \times \mathrm{g}$. Aliquots of each sample were spotted on Whatmann 3-mm filter disks, processed through trichloroacetic acid (TCA), and counted in a liquid scintillation counter to determine total acid-precipitable protein radioactivity.

Equal amounts of radiolabeled protein $\left(5 \times 10^{5} \mathrm{dpm}\right)$ from experimental and contralateral control DRGs from the same animal were used for 2-dimensional polyacrylamide gel electrophoresis (2D-PAGE) and fluorography as previously described (Oblinger et al., 1987). Fluorography was done on Kodak XAR-5 film for 0.5-5 d to visualize the labeled proteins. To quantify the level of incorporation of radioactivity into various proteins during the pulse label, fluorographs were used as guides to locate and excise spots from the gels. The gel pieces were dissolved in $30 \% \mathrm{H}_{2} \mathrm{O}_{2}$ at $60^{\circ} \mathrm{C}$, mixed with $5 \mathrm{ml}$ of scintillation cocktail, and counted in a liquid scintillation counter. Synthesis of NF-L (68 $\mathrm{kDa}$ ) and the entire tubulin complex was quantified in this manner. Data from 4 experiments (different ganglia) per time point and condition were averaged. For graphical purposes, the mean dpm incorporated into NF-L and tubulin in axotomized DRGs was expressed as a percentage of that in contralateral control DRGs at the different postaxotomy times. For statistical comparisons, differences in the mean dpm incorporated into the various proteins in experimental versus contralateral control DRGs and between the NGF-treated and saline-treated DRGs were assessed using the Student's $t$ test $(p<0.05)$.

RNA slot blot analysis. RNA was isolated from experimental (both NGF-treated or saline-treated) L4 and L5 DRGs, contralateral DRGs, and normal (untreated) DRGs by the acid guanidinium thiocyanatephenol-chloroform extraction method (Chomcyznski and Sacchi, 1987). Two $\mu \mathrm{g}$ of total RNA were loaded into wells of a slot blot apparatus (American Bionetics) and vacuum filtered onto Nytran membranes (Schleicher \& Schuell) according to manufacturer's instructions. The membranes were baked in a vacuum oven at $80^{\circ} \mathrm{C}$ for $2 \mathrm{hr}$ and then hybridized sequentially to ${ }^{32} \mathrm{P}$-labeled cDNA probes to NF-L (Lewis
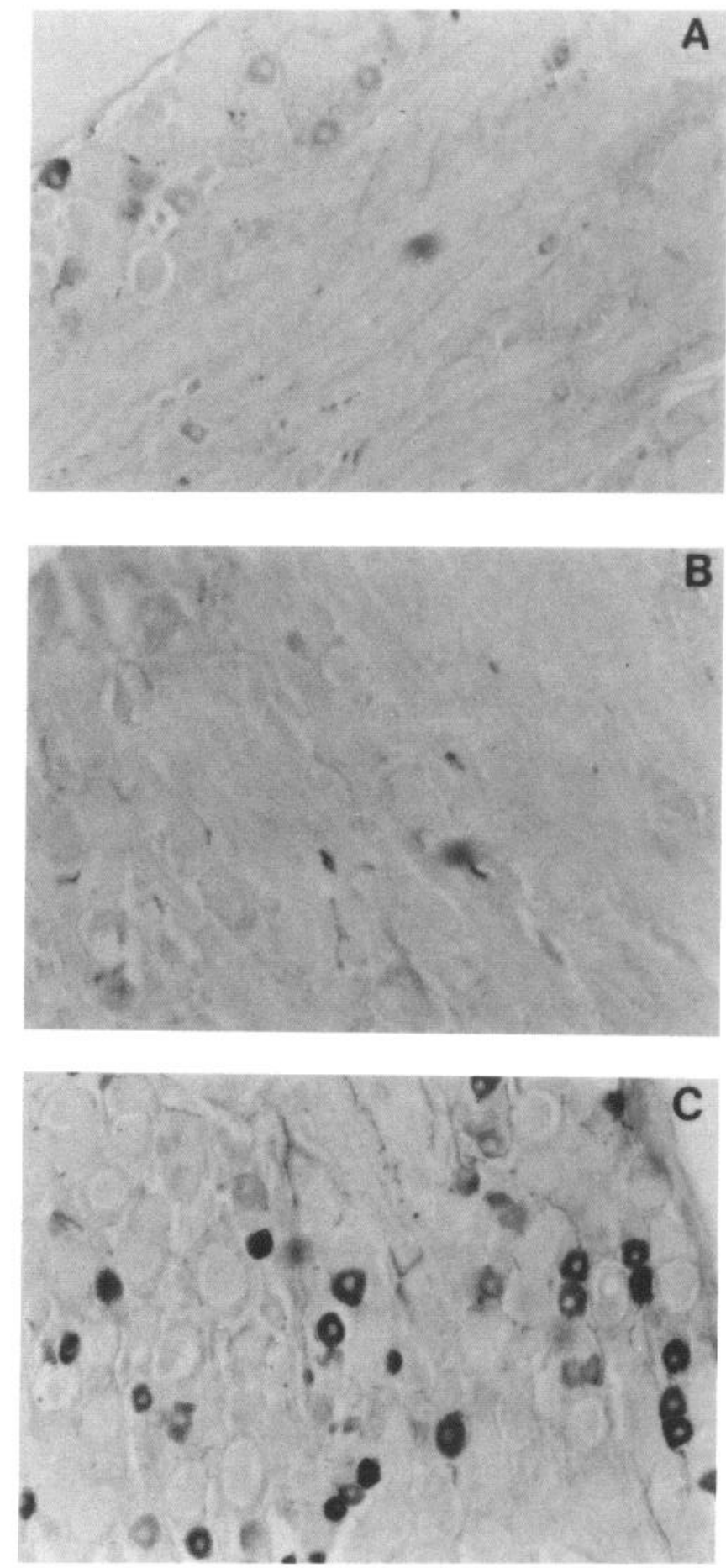

Figure 1. Immunocytochemistry of DRG neurons using polyclonal antibody against substance $P$. The panels show a normal control DRG $(A)$, a saline-treated DRG at $12 \mathrm{~d}$ after axotomy $(B)$, and a NGF-treated DRG at $12 \mathrm{~d}$ after axotomy $(C)$. Note the disappearance of immunoreactivity in the saline-treated axotomy condition and the marked increase in staining of NGF-treated axotomized neurons.

and Cowan, 1985) and $\beta$-tubulin (Bond et al., 1984). Final stringency of the washes was $0.1 \times \mathrm{SSC}$ with $0.1 \%$ SDS at $40^{\circ} \mathrm{C}$. After each hybridization, autoradiographs were made by exposing Kodak XAR 5 film to the blots for 1-4 d. To strip labeled probes from the blots prior to hybridization with the next probe, blots were immersed in boiling water with $0.1 \%$ SDS for $5 \mathrm{~min}$. 


\section{Control}

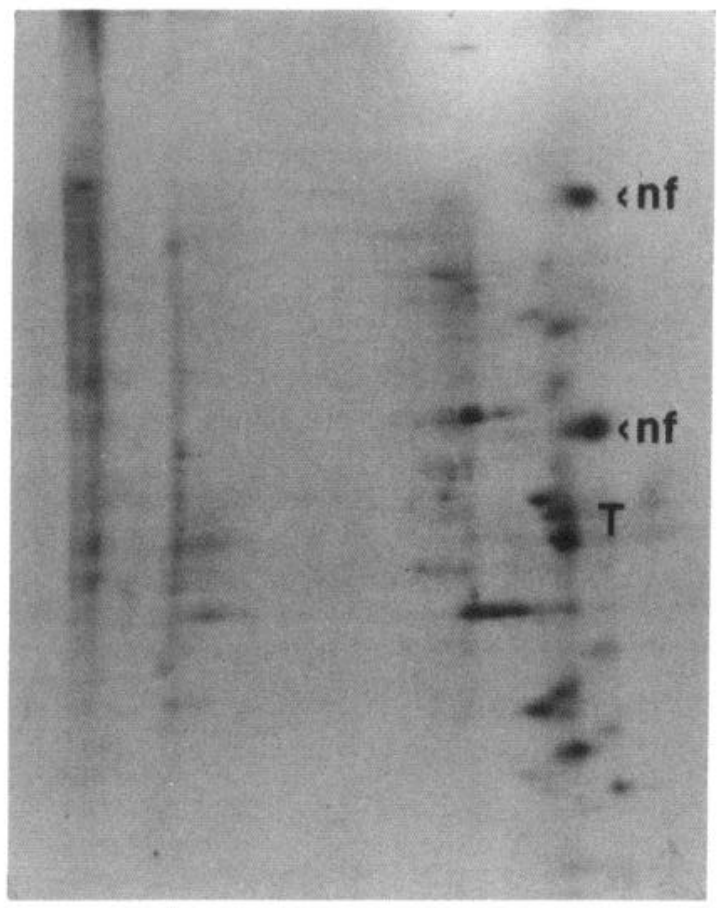

NGF + Axotomy

12d

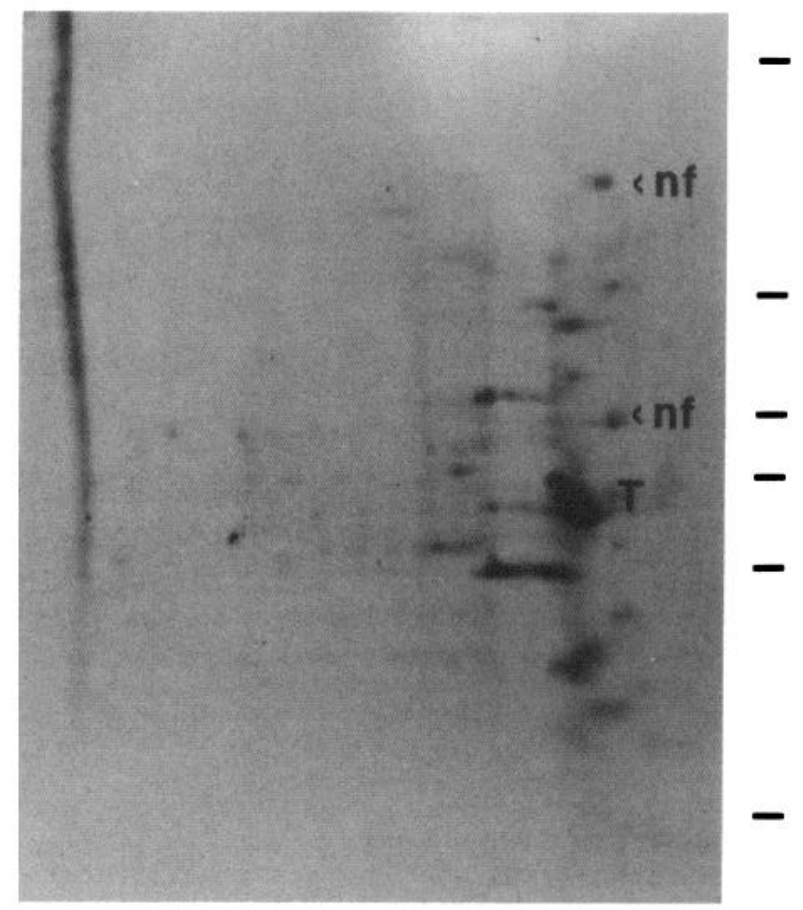

Figure 2. Fluorographs of 2D gels showing DRG proteins labeled during 1-hr pulse-label with ${ }^{35}$ S-methionine : cysteine in vitro. Labeled proteins in a contralateral control L4 DRG (left) and an NGF-treated axotomized L4 DRG at $12 \mathrm{~d}$ postaxotomy (right) are shown. The positions of 2 of the NF proteins $(<n f)$ and tubulins $(T)$ are indicated. The horizontal bars to the right of the gel panels correspond from top to bottom, to the following MW standards: $200,97,68,57,43$, and $14 \mathrm{kDa}$.

\section{Results}

NGF treatment increases the immunodetectable level of substance $P$ in axotomized DRG neurons

Immunocytochemistry of sections of normal, untreated rat DRG neurons with a polyclonal antibody against substance $P$ showed light staining of a number of small-sized neurons and dark staining of only a few neurons in each section (Fig. 1A). Two types of axotomized preparations were next examined: saline-treated, transected DRGs and NGF-treated, transected DRGs. In both, the right sciatic nerves were transected at the midthigh level, and the proximal nerve stumps were continuously infused with either NGF or saline via osmotic minipumps for periods of 1$12 \mathrm{~d}$. In axotomized preparations treated with saline for $12 \mathrm{~d}$, no detectable staining of neurons for substance $P$ was found (Fig. 1B). At $1 \mathrm{~d}$ after axotomy and saline treatment, a few substance P-positive cells were observed, but by $7 \mathrm{~d}$ after axotomy, no staining was observed in any of the animals examined (data not shown). In contrast, NGF treatment of axotomized DRG neurons resulted in a dramatic increase in the immunodetectable levels of substance $P$ by $12 \mathrm{~d}$ (Fig. 1C). Many more small neurons were stained in the NGF-treated preparations compared to normal. The intensity of staining in the NGFtreated, axotomized preparations was considerably darker than that of normal, untreated control neurons (Fig. 1). Increases in substance P immunoreactivity in DRG cells were also observed $7 \mathrm{~d}$ after axotomy coupled with NGF treatment, but the level of increase was not as robust as that present at $12 \mathrm{~d}$ (data not shown). These results indicated that NGF treatment not only rescued substance $P$ levels in axotomized DRG neurons, but that it also augmented the levels of immunodetectable substance P over those present normally in the DRG.

\section{$N G F$ administration to axotomized DRGs does not alter NF-L or tubulin synthesis}

Protein synthesis was examined in experimental (either NGFtreated or saline-treated) and contralateral control DRGs 1, 7, and $12 \mathrm{~d}$ after axotomy. The level of synthesis of NF proteins and tubulin was assessed using quantitative 2D-PAGE/fluorography after a 1-hr in vitro pulse label of the DRG. Fluorographs revealed that the synthesis patterns in axotomized, NGF-treated DRGs (Fig. 2) were nearly identical to those in axotomized, saline-treated DRGs (not shown). In both cases, decreases in the labeling of the NF proteins and increases in labeling of the tubulins were present in the axotomized preparations compared to contralateral controls. Figure 2 shows representative examples of the protein synthesis patterns at $12 \mathrm{~d}$ postaxotomy in an NGF-treated, axotomized DRG and its contralateral control. The level of incorporation into both NF-L ( $68 \mathrm{kDa}$ ) and medium-MW NF protein (NF-M; $\sim 145 \mathrm{kDa}$ ) was markedly less in the axotomized DRG than in the control DRG (Fig. 2). The synthesis of the high-MW NF protein (NF-H) was not specifically examined in the present study for the following reason. NF-H is known to undergo extensive posttranslational modification that affects its migration on 2D gels (Oblinger, 1987). The nascent unmodified NF-H protein that is present after a 1-hr pulse-labeling experiment was not consistently resolved 
sufficiently within the $\mathrm{pH}$ range of the $2 \mathrm{D}$ gels used in the present study.

Quantification of protein synthesis was done by excising the NF-L and tubulin proteins from the 2D gels using the fluorographs as guides, dissolving the gel pieces, and determining their radioactivity by liquid scintillation counting. Synthesis of NF-L and tubulin in axotomized DRGs at different times after axotomy was expressed as a percentage of that in contralateral control DRGs (Fig. 3). In saline-treated axotomized DRGs, tubulin synthesis was $150 \%$ of contralateral controls at $7 \mathrm{~d}$ after axotomy, while NF-L synthesis was reduced to $66 \%$ and $63 \%$ of control at 7 and $12 \mathrm{~d}$, respectively (Fig. 3A). In NGF-treated, axotomized DRGs, tubulin synthesis was $123 \%$ of control at 7 $d$, and NF-L synthesis was $67 \%$ and $43 \%$ of control at 7 and 12 d, respectively (Fig. 3B). The changes were quite consistent in 4 separate experiments using different animals. Statistical comparisons of the mean radioactivity (dpm) incorporated into NF-L and tubulin proteins in the different conditions showed that, while axotomy had a significant effect on the synthesis of NF-L at 7 and $12 \mathrm{~d}$ postaxotomy in both in the NGF- and the salinetreatment conditions $(p<0.05)$, no significant differences in the level of synthesis of NF-L or tubulin existed between NGF- and saline-treatment conditions. These results demonstrated that NGF did not ameliorate the axotomy-induced changes in NF and tubulin synthesis in DRG neurons.

$N G F$ has no effect on the time course of changes in NF-L and $\beta$-tubulin mRNA levels in axotomized DRG neurons

In situ hybridization with ${ }^{35} \mathrm{~S}$-labeled $\mathrm{cDNA}$ probes was used to examine NF-L and $\beta$-tubulin mRNA levels in large-sized $\left(>1000 \mu \mathrm{m}^{2}\right)$ DRG neurons at different times after axotomy and either NGF or saline treatment. Visual comparisons of autoradiograms of NGF-treated, axotomized neurons and saline-treated, axotomized neurons at $12 \mathrm{~d}$ postaxotomy showed a marked reduction in NF-L mRNA levels (a reduced number of silver grains over neuronal cell bodies) and a robust increase in $\beta$-tubulin mRNA levels in the injured neurons compared to normal controls (Fig. 4). The examples shown are randomly selected neurons. In all ganglia, some of the axotomized neurons exhibited a substantial change in labeling, while other neurons showed more modest alterations.

Quantification of the mean grain densities of at least 100 largesized DRG neurons per postaxotomy time point and treatment condition using a computer-based image analysis system was done to determine the changes in NF- $L$ and $\beta$-tubulin mRNA levels. The data for mRNA levels in axotomized neurons were expressed as a percentage of those in normal control neurons (Fig. 5). NF-L mRNA levels were $51 \%$ of normal in NGFtreated neurons (Fig. $5 B$ ) and $65 \%$ of normal in saline-treated neurons (Fig. $5 A$ ) at $12 \mathrm{~d}$ postaxotomy. The $\beta$-tubulin mRNA levels were $202 \%$ of normal in NGF-treated neurons (Fig. $5 B$ ) and $170 \%$ of normal in saline-treated neurons (Fig. $5 \mathrm{~A}$ ) at $12 \mathrm{~d}$ postaxotomy. Statistical comparisons of the various conditions revealed that the mean grain densities for NF-L in NGF-treated neurons were significantly lower than those in control neurons at 7 and $12 \mathrm{~d}$ postaxotomy $(p<0.05)$, while the levels of labeling for $\beta$-tubulin mRNA in the NGF-treated neurons at 1,7 , and $12 \mathrm{~d}$ after axotomy were significantly greater $(p<0.05)$ than those in controls (data not shown). This was also true for the saline-treatment condition. Comparison of the level of labeling of NGF-treated, axotomized DRG neurons versus saline-treated, axotomized neurons revealed no statistically significant dif-
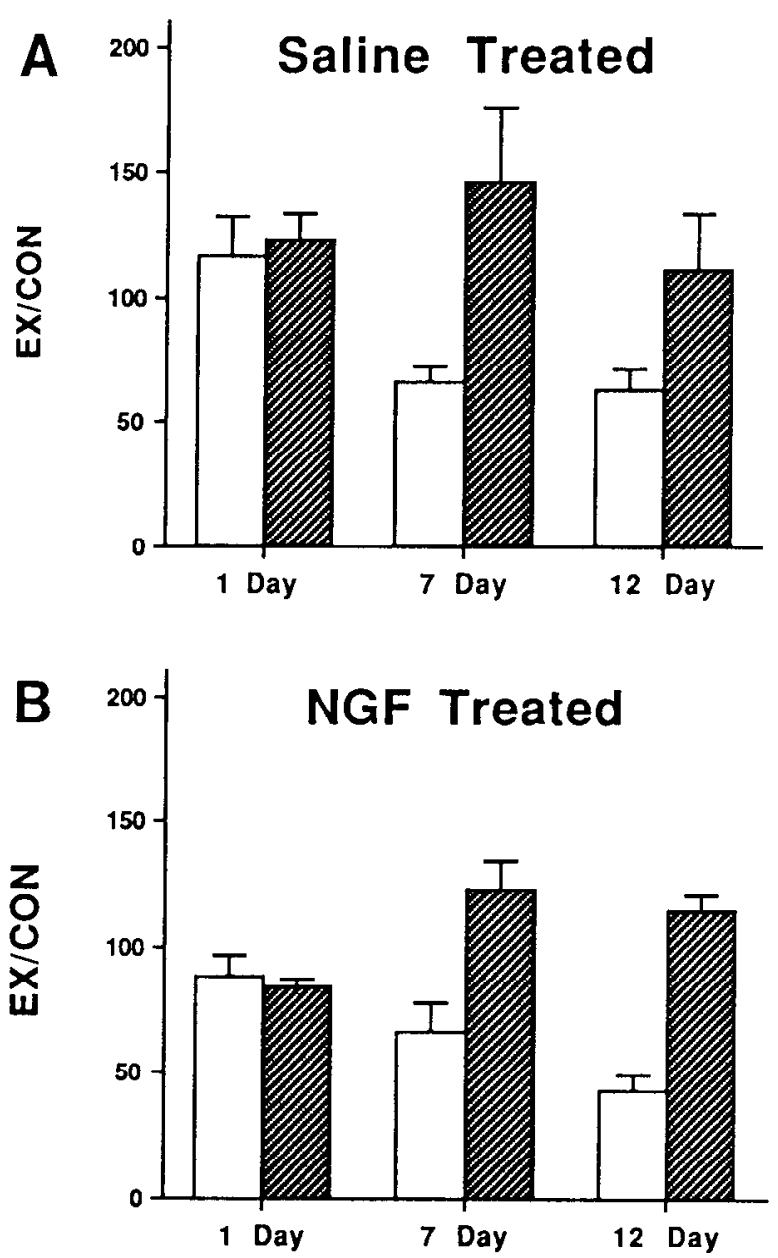

Figure 3. Quantification of synthesis of NF-L and tubulin proteins in DRGs from 1 to $12 \mathrm{~d}$ after axotomy and either saline $(A)$ or NGF $(B)$ treatment. DRGs were labeled with ${ }^{35} \mathrm{~S}$-methionine : cysteine in vitro for $1 \mathrm{hr}$, and proteins were separated by 2D-PAGE. NF-L and $\beta$-tubulin proteins were excised from $2 D$ gels using fluorographs as guides, and the radioactivity in each was determined by liquid scintillation counting. The mean protein radioactivity (dpm) incorporated into NF-L or tubulin in experimental (axotomized) DRGs is expressed as a percentage of that in contralateral control DRGs $(E X / C O N)$. The open bars show changes in the labeling of NF-L at $1(n=4), 7(n=4)$, and $12 \mathrm{~d}(n=$ 4) after axotomy. The hatched bars show changes in the relative level of tubulin synthesis of experimental-versus contralateral control DRGs at $1(n=4), 7(n=4)$, and $12 \mathrm{~d}(n=4)$ after axotomy. Error bars represent SEM.

ferences between these treatment conditions at any postaxotomy time. These results demonstrated that administration of exogenous NGF did not alter the axotomy-induced changes in NF-L or tubulin mRNA levels in DRG neurons.

RNA slot blots were also used to examine the levels of NF-L and $\beta$-tubulin mRNAs in axotomized DRG neurons (Fig. 6). For these experiments, total RNA was isolated from experimental DRGs at different times after axotomy and NGF treatment or saline treatment, from contralateral control DRGs from each of the treatment groups, and from normal control DRGs. Equal amounts of RNA from the various conditions were blotted onto nylon membranes, and the relative abundance of NF-L and tubulin mRNA in the various conditions was assessed on autoradiograms following hybridizations with ${ }^{32}$ P-labeled cDNA probes. Blots were done in triplicate using pooled total RNA obtained from DRGs from 3 rats per postaxotomy time point 

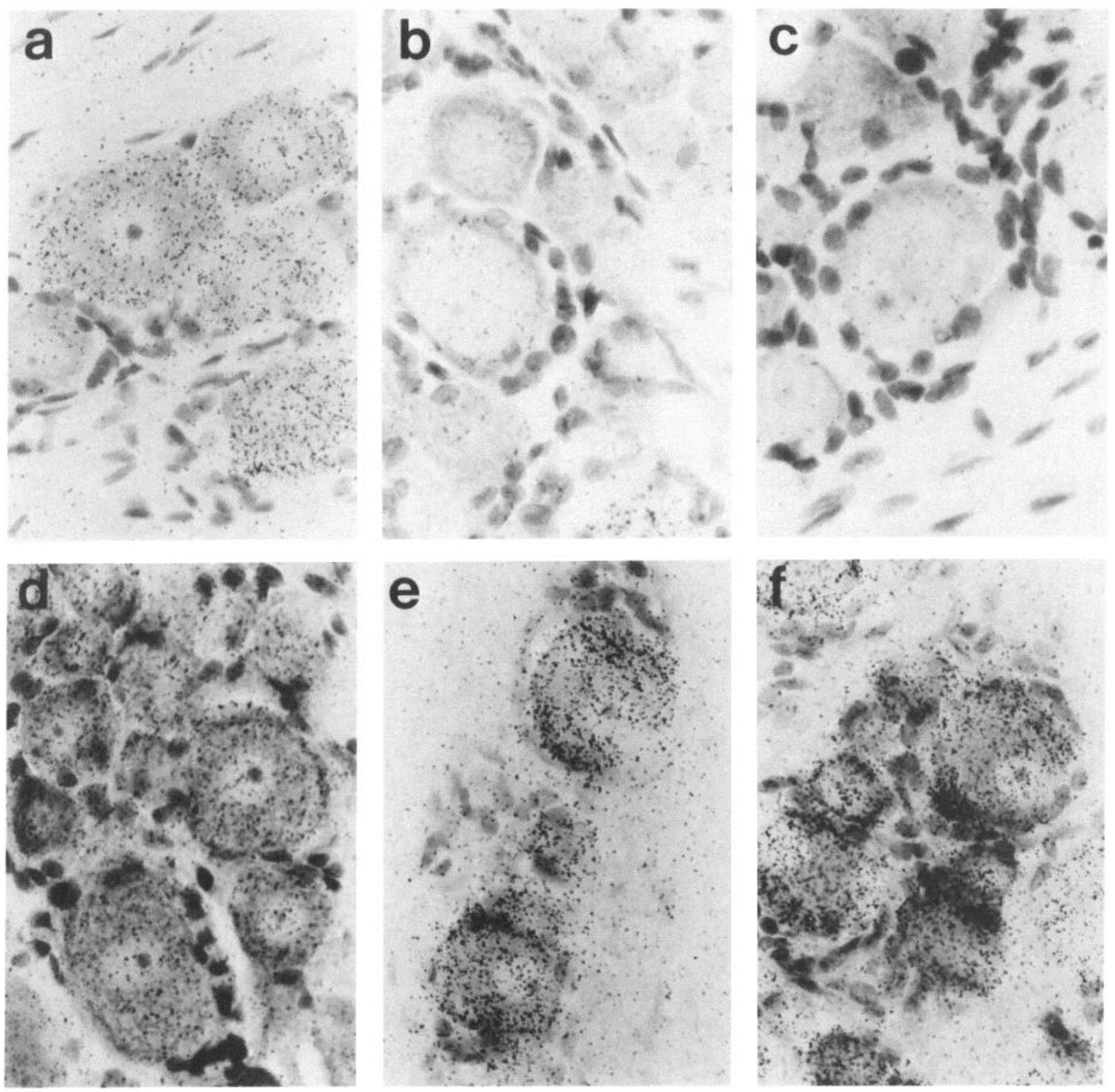

Figure 4. Localization of NF-L and $\beta$-tubulin mRNAs within sensory neurons by in situ hybridization with ${ }^{35} \mathrm{~S}$-labeled cDNA probes. The autoradiograms of normal control DRG neurons $(a)$, saline-treated neurons ( $12 \mathrm{~d}$ after axotomy; $b$ ), and NGF-treated neurons (12 d after axotomy; c) were obtained from sections of DRGs hybridized with a ${ }^{35} \mathrm{~S}$-labeled NF-L cDNA probe and exposed for $3 \mathrm{~d}$. In the lower row of panels, the autoradiograms were obtained from sections of normal control neurons $(d)$, saline-treated axotomized neurons (12 d after axotomy; $e$ ), and NGFtreated axotomized neurons ( $12 \mathrm{~d}$ after axotomy; $f$ ) that were hybridized with a labeled $\beta$-tubulin cDNA and exposed for $4 \mathrm{~d}$.

and condition. The results were quite similar to those obtained in the in situ hybridization experiments. As shown in Figure 6, autoradiograms of slot blots showed that NF-L mRNA levels in axotomized DRGs (either NGF-treated or saline-treated) were reduced compared to the levels in contralateral control and normal control DRGs at 7 and $12 \mathrm{~d}$ postaxotomy (Fig. 6, top). At these same time points, $\beta$-tubulin mRNA levels in axotomized DRGs were increased over control levels (Fig. 6, bottom). These results supported those from in situ hybridization experiments and showed that administration of exogenous NGF to axotomized DRG neurons did not ameliorate the injury-induced changes in NF or tubulin gene expression.

\section{Discussion}

The importance of NGF as a trophic factor for sensory neurons in the adult animal has been somewhat unclear. During early development, it is well established that DRG neurons are dependent on NGF for survival (Levi-Montalcini and Angeletti, 1968). However, unlike sympathetic neurons, which exhibit continued NGF dependence for both survival and maintenance of normal differentiated features for the life of the animal (LeviMontalcini and Angeletti, 1968; Thoenen and Barde, 1980; Ruit et al., 1990), most adult DRG neurons are no longer strictly dependent on NGF for survival (Johnson et al., 1986). However, 
sciatic nerve transection in adult rats reportedly causes cell losses of 9-19\% in lumbar DRGs by $30 \mathrm{~d}$ and losses of $30-40 \%$ after 3 months (Arvidsson et al., 1986). A single dose of NGF administered via an implanted silicone tube around the nerve stump reportedly prevents cell losses for 4 weeks after nerve transection (Otto et al., 1987). Thus, some limited contribution of NGF towards survival of adult sensory neurons cannot yet be ruled out. The presence of receptors for NGF in mature DRG neurons (Richardson et al., 1986) and evidence that NGF is retrogradely transported by mature DRG cells (Richardson and Riopelle, 1984) also suggest that NGF is important in some way to adult sensory neurons. NGF may be necessary for maintaining various aspects of biochemical, morphological, and functional homeostasis in adult sensory neurons.

The axotomy model has often been used to explore the role of target-derived trophic factors in neuronal metabolism and function. A number of neuronal responses to axotomy have been well characterized, but the signal(s) for these responses are still unclear (Lieberman, 1971). One class of axotomy-induced responses is the downregulation of neurotransmitter/neuromodulator molecules such as substance $P$. It is now fairly well established that NGF is involved in regulating substance $P$ expression (Goedert et al., 1981; Fitzgerald et al., 1985; Lindsay and Harmar, 1989). Substance $P$ levels are increased in the DRG in rats treated with NGF and decreased in the DRG when rats are exposed to NGF antibodies (Kessler and Black, 1980; Otten et al., 1980). In animals deprived of NGF by an autoimmune paradigm, substance $P$ levels in the DRG are also substantially reduced (Schwartz et al., 1982). When the retrograde transport of NGF is disrupted by axotomy, substance $P$ expression in DRG cells had been shown to be downregulated (Miller et al., 1982; Schwartz et al., 1982; Fitzgerald et al., 1985; Bisby and Keen, 1986; Nielsch and Keen, 1988). NGF replacement therapy in axotomized neurons can substantially increase substance $P$ levels in axotomized DRG cells (Fitzgerald et al., 1985).

In the present study, we exploited substance $P$ as a positive control for our NGF administration paradigm. In axotomized DRG neurons treated with exogenous NGF by osmotic minipumps for $12 \mathrm{~d}$, we found that NGF replacement prevented the downregulation in substance $P$ levels seen in saline-treated axotomized DRG neurons. In addition, NGF administration actually caused an increase in the level of substance $P$ in axotomized neurons over that found in normal, untreated control neurons. From our present results, we do not know where NGF is acting to regulate substance $P$ expression. However, recent findings indicate that substance $P$ levels are regulated at a pretranslational level by axotomy. That is, axotomy lowers both the level of the substance $P$ peptide and the levels of the preprotachykinin mRNA in DRG cclls (Niclsch and Keen, 1988). Future studies will reveal whether or not NGF administration is also effective in rescuing the mRNA levels of the substance $P$ precursor in DRG neurons. Our results support previous findings that NGF is essential for substance $P$ expression in the DRG. Important to the remainder of the study, they also demonstrate that the NGF administration paradigm used in this study is quite effective.

Another well-studied class of axotomy-induced responses is the set of changes in expression of cytoskeletal proteins. Previous studies have demonstrated major changes in the expression of NF proteins, tubulin, actin, and their associated mRNA species in axotomized DRG neurons (Oblinger and Lasek, 1985, 1988; Hoffman et al., 1987; Wong and Oblinger 1987, 1990a,b; Gold-
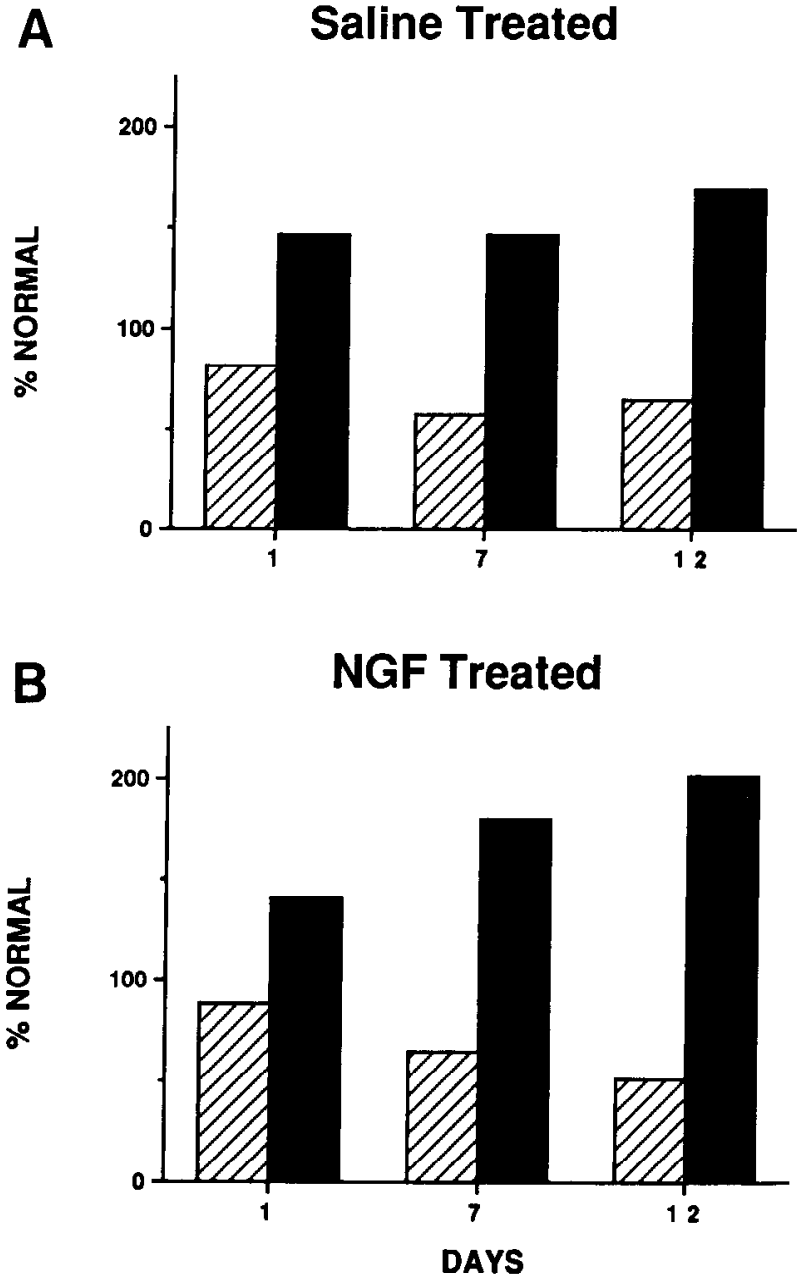

Figure 5. Quantification of NF-L and $\beta$-tubulin $m$ RNA changes in saline-treated $(A)$ and NGF-treated $(B)$ axotomized neurons by in situ hybridization. The hatched bars represent data for NF-L mRNA changes, and the solid bars represent data for $\beta$-tubulin mRNA changes. The average experimental versus control values are plotted as percentages. To derive these values, mean grain densities (average number of silver grains per $\mu \mathrm{m}^{2}$ of cell area) were determined from 4 experimental ganglia per treatment condition and from 3 untreated normal control ganglia. In each case, grain density measurements were made of 25 randomly selected neurons per ganglion, and only large neurons $\left(>1000 \mu \mathrm{m}^{2}\right)$ in which a clearly defined nucleus and nucleolus were present were used for grain counting.

stein et al., 1988; Greenberg and Lasek, 1988; Hoffman and Cleveland, 1988; Oblinger et al., 1989). In the present study, NGF replacement therapy to axotomized DRG neurons was done to examine the hypothesis that a reduction in the retrograde supply of NGF is involved in the cytoskeletal protein changes that occur in axotomized DRG neurons. This hypothesis was derived from consideration of a number of previous observations that suggested that NGF is important in regulating cytoskeletal protein expression. For example, NGF increases the expression of NF proteins and their mRNAs (Lee et al., 1982; Lee, 1985; Lindenbaum et al., 1987) and modulates tubulin mRNA levels (Fernyhough and Ishii, 1987) in cultured PC12 cells. Alterations in the stability of microtubules (Black and Greene, 1982; Drubin et al., 1985) and posttranslational modifications of tubulin (Black and Keyser, 1987) also result after NGF administration. While it seemed plausible that de- 
(NF-L)

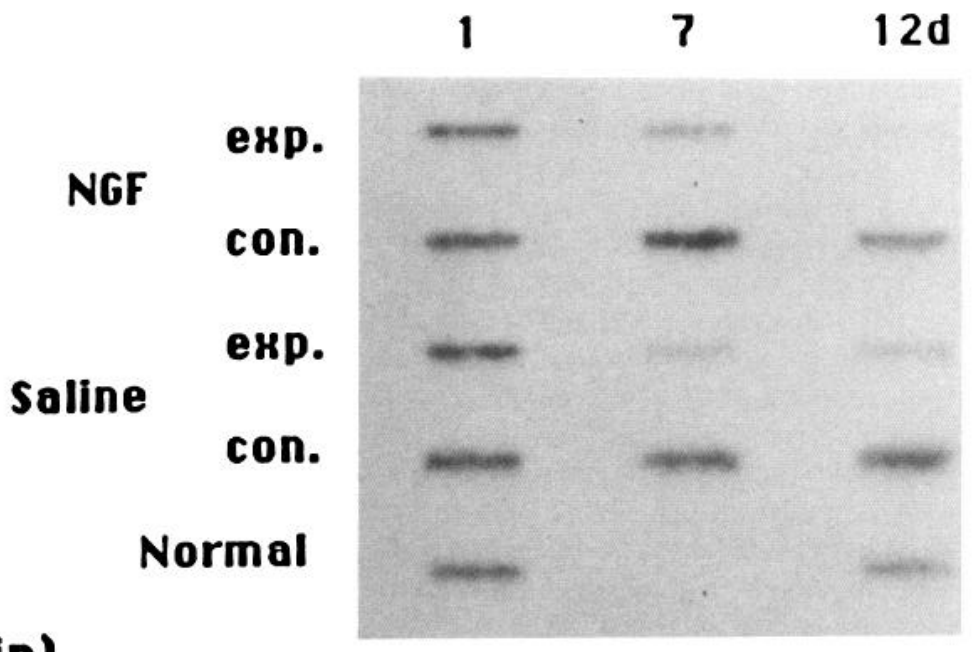

\section{(Tubulin)}

Figure 6. Autoradiograms of RNA slot blots hybridized with ${ }^{32} \mathrm{P}$-labeled cDNAs specific for NF-L and $\beta$-tubulin mRNAs. Each slot contained $2 \mu \mathrm{g}$ of total RNA isolated from DRGs, except for the center column slot in the rows labeled "normal" (untreated DRG condition), which did not contain RNA. The experimentally axotomized (exp) and contralateral control (con) samples for both the $N G F$ - and saline-treatment conditions at the indicated days $(1,7$, $12 d$ ) after axotomy are labeled.

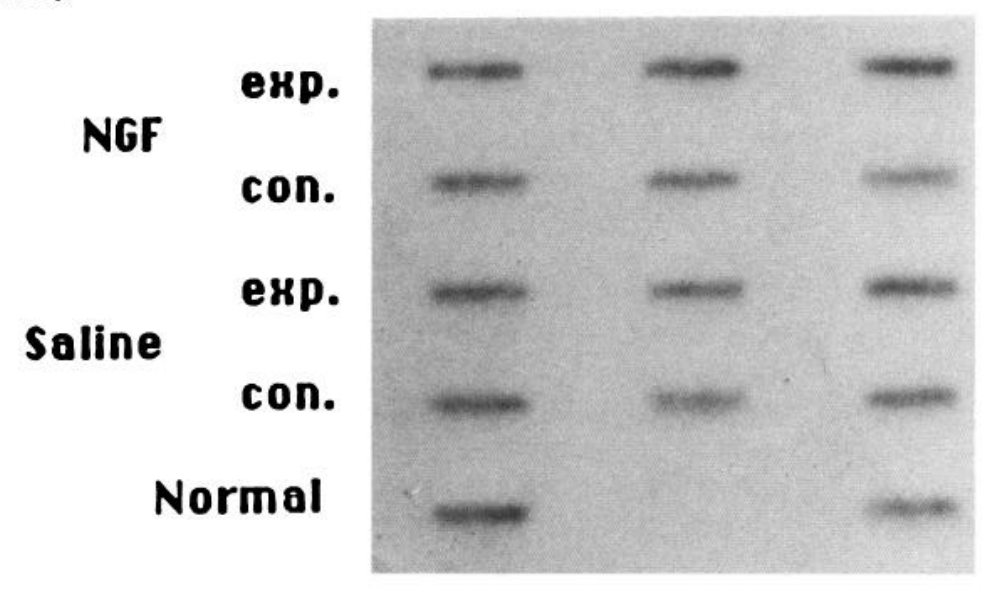

creases in the level of retrogradely supplied NGF are involved in the cytoskeletal response to axotomy, the results of the present study refuted this hypothesis.

Our pulse-labeling studies showed that both NGF-treated and saline-treated axotomized DRGs had very similar profiles with respect to NF and tubulin synthesis. DRGs in both conditions showed equivalent reductions in NF-L synthesis and similar increases in tubulin synthesis. At the mRNA level, NGF-treated and saline-treated axotomized DRG neurons also showed similar changes-decreases in NF-L mRNA and increases in $\beta$-tubulin mRNA levels. Although our overall conclusion is that NGF treatment does not prevent the changes in cytoskeletal gene expression in axotomized DRG neurons, we cannot yet exclude the possibility that cytoskeletal gene expression was rescued in small-sized DRG neurons because we examined by in situ hybridization the mRNA levels of NF and tubulin in only the large-sized DRG cell population. The small-sized DRG neurons normally express only low levels of NF mRNAs (Hoffman et al., 1987; Wong and Oblinger, 1987) but do contain significant levels of tubulin mRNA (Hoffman et al., 1987; Wong and Oblinger, 1990a). We consider it unlikely that we would not have detected some evidence of rescue of tubulin expression, if such a change occurred in a significant number of small neurons, by our RNA blot experiments. However, the detailed analyses of small-sized DRG neurons by in situ hybridization remain to be done to resolve this question.
In contrast to our present findings on large-sized DRG neurons, Verge et al. (1990) recently suggested that NF-M mRNA levels may be rescued in a small number of large-sized DRG neurons that were axotomized and treated with NGF. In that study, a small subpopulation of axotomized DRG neurons that had both high levels of NF-M mRNA expression and significant levels of high-affinity NGF receptors showed a tendency for recovery of NF-M mRNA levels after NGF treatment. The investigators demonstrated in that study that the factors regulating expression of the genes for the NGF receptor and the NF proteins seem to be largely independent of one another because no correlation could be established between the expression NF-M mRNA and NGF binding in the adult rat DRG. This, coupled with the very small number of DRG cells apparently rescued by NGF, suggests that the rescue of these cells may simply have been a fortuitous event, rather than one that has general biological significance. The fact that we did not detect a change in our present study using 3 different methods of assessing NF and tubulin expression in the DRG supports this contention.

The mechanism of action of NGF in cells is still unclear. Studies of PC12 cells have shown that the effects of NGF are at both transcriptional and posttranscriptional levels and are produced indirectly via second messengers (Traynor et al., 1982; Bellini et al., 1988; Cho et al., 1989). The effects of NGF on cultured cells can be mimicked by phorbol ester derivatives and calcium ionophores (Doherty et al., 1988), and the ability of 
NGF to induce neurites in PC12 cells can be enhanced by dibutyryl cAMP (Heidemann et al., 1985). Because many second messengers activate kinases, the effects of NGF may be mediated by phosphorylation of gene regulatory proteins. Recently, 2 reports have shown that one of the genes rapidly induced by NGF codes for a transcription initiation factor (Milbrandt, 1987; Cho et al., 1989). Cytoskeletal proteins and substance $P$ are not in the family of genes that change their expression rapidly after NGF treatment. Preprotachykinin mRNA levels in DRG cultures, for example, are not noticeably increased until $24 \mathrm{hr}$ after NGF stimulation (Lindsay and Harmar, 1989). The mechanism of regulation of genes that are more slowly responsive to NGF is completely unknown, and elucidation of this will be an important goal in future studies.

The search for factors that trigger and maintain various aspects of the axotomy response in neurons continues. It is clear that axon-target interactions must ultimately play a role in maintaining normal levels of protein expression in neurons. However, the role of target-derived trophic factors such as NGF is undoubtedly complex. NGF may play an important role in the axon regeneration process by being both a haptotactic agent (Taniuchi et al., 1988) and a chemotactic agent (Ebendal et al., 1983; Larkfors et al., 1987). However, a reduction in the level of retrograde supply of NGF is clearly not the only axotomyinduced signal that DRG neurons recognize. With respect to the robust response of the cytoskeletal genes in axotomized neurons, it is now clear that exogenous NGF does not ameliorate the response. The results of the present study suggest that NGF has a negligible role in the regulation of cytoskeletal genes in mature axotomized neurons in vivo.

\section{References}

Arvidsson J, Ygge J, Grant G (1986) Cell loss in lumbar dorsal root ganglia and transganglionic degeneration after sciatic nerve resection in the rat. Brain Res 373:15-21.

Bellini F, Toffano G, Bruni A (1988) Activation of phosphoinositide hydrolysis by nerve growth factor and lysophosphatidylserine in rat peritoneal mast cells. Biochim Biophys Acta 970:187-193.

Bisby MA, Keen P (1986) Regeneration of primary afferent neurons containing substance P-like immunoreactivity. Brain Res 365:85-95.

Black MM, Greene LA (1982) Changes in the colchicine susceptibility of microtubules associated with neurite outgrowth: studies with nerve growth factor-responsive PC12 pheochromocytoma cells. J Cell Biol 95:379-386.

Black MM, Keyser P (1987) Acetylation of alpha-tubulin in cultured neurons and the induction of alpha-tubulin acetylation in PC12 cells by treatment with nerve growth factor. J Neurosci 7:1833-1842.

Bond JF, Robinson GS, Farmer SR (1984) Differential expression of two neural cell-specific $\beta$-tubulin mRNAs during rat brain development. Mol Cell Biol 4:1313-1319.

Bradford MM (1976) A rapid and sensitive method for the quantitation of microgram quantities of protein utilizing the principle of protein-dye binding. Anal Biochem 72:248-254.

Burk RR, Eschenbruch M, Leuthard P, Steck G (1983) Sensitive detection of proteins and peptides in polyacrylamide gels after formaldehyde fixation. Methods in Enzymol 91:247-254.

Cho K-O, Skarnes WC, Minsk B, Palmieri S, Jackson-Grusby L, Wagner JA (1989) Nerve growth factor regulates gene expression by several distinct mechanisms. Mol Cell Biol 9:135-143.

Chomcyznski P, Sacchi N (1987) Single-step method of RNA isolation by acid guanidinium thiocyanate-phenol-chloroform extraction. Anal Biochem 162:156-159.

Claude P, Hawrot E, Dunis DA, Campenot RB (1982) Binding, internalization, and retrograde transport of ${ }^{125}$ I-nerve growth factor in cultured rat sympathetic neurons. J Neurosci 2:431-442.

Doherty P, Mann DA, Walsh FS (1988) Comparison of the effects of $\mathrm{NGF}$, activators of protein kinase $\mathrm{C}$, and a calcium ionophore on the expression of Thy-1 and N-CAM in PC12 cell cultures. J Cell Biol 107:333-340.

Drubin DG, Feinstein SC, Shooter EM, Kirschner MW (1985) Nerve growth growth factor-induced neurite outgrowth in PC1 2 cell involves the coordinate induction of microtubule assembly and assembly-promoting factors. J Cell Biol 101:1799-1807.

Ebendal T, Olson L, Seiger A (1983) The level of nerve growth factor (NGF) as a function of innervation. Exp Cell Res 148:311-317.

Fernyhough P, Ishii DN (1987) Nerve growth factor modulates tubulin transcript levels in pheochromocytoma PC12 cells. Neurochem Res 12:891-899.

Fitzgerald M, Wall PD, Gocdert M, Emson PC (1985) Nerve growth factor counteracts the neurophysiological and neurochemical effects of chronic sciatic nerve section. Brain Res 332:131-141.

Goedert M, Stoeckel K, Otten K (1981) Biological importance of the retrograde axonal transport of nerve growth factor in sensory neurons. Proc Natl Acad Sci USA 78:5895-5898.

Goldstein ME, Weiss SR, Lazzarini RA, Shneidman PS, Lees JF, Schlaepfer WW (1988) mRNA levels of all three neurofilament proteins decline following nerve transection. Mol Brain Res 3:287292.

Gorin PD, Johnson EM Jr (1979) Experimental autoimmune model of nerve growth factor deprivation: effects on developing peripheral sympathetic and sensory neurons. Proc Natl Acad Sci USA 76:53825386.

Greenberg SE, Lasek RJ (1988) Ncurofilament protcin synthesis in DRG neurons decreases more after peripheral axotomy than central axotomy. J Neurosci 8:1739-1746.

Greene LA, Tischler AS (1982) PC12 pheochromocytoma cultures in neurobiological research. Adv Cell Neurobiol 3:373-414.

Heidemann SR, Joshi HC, Schechter A, Fletcher JR, Bothwell M (1985) Synergistic effects of cyclic AMP and nerve growth factor on neurite outgrowth and microtubule stability of PC12 cells. J Cell Biol 100: 916-927.

Heumann R, Korsching S, Bandtlow C, Thoenen H (1987a) Changes of nerve growth factor synthesis in nonneuronal cells in response to sciatic nerve transection. J Cell Biol 104:1623-1631.

Heumann R, Lindhold D, Bandtlow C, Meyer M, Radeke MJ, Miski TP, Shooter E, Thoenen H (1987b) Differential regulation of mRNA encoding nerve growth factor and its receptor in rat sciatic ncrve during development, degeneration and regeneration: role of macrophages. Proc Natl Acad Sci USA 84:8735-8739.

Hoffman PN, Cleveland DW (1988) Neurotilament and tubulin expression recapitulates the developmental program during axonal regeneration: induction of a specific $\beta$-tubulin isotype. Proc Natl Acad Sci USA 85:4530-4533.

Hoffman PN, Lasek RJ (1980) Axonal transport of the cytoskeleton in regenerating motor neurons: constancy and change. Brain Res 202: 317-333.

Hoffman PN, Cleveland DW, Griffin JW, Landes PW, Cowan NJ, Price DL (1987) Neurofilament gene expression: a major determinant of axonal caliber. Proc Natl Acad Sci USA 84:3472-3476.

Johnson EM Jr, Rich KM, Yip HK (1986) The role of NGF in sensory neurons in vivo. Trends Neurosci 9:33-37.

Kessler JT, Black IB (1980) Nerve growth factor stimulates the development of substance P in sensory ganglia. Proc Natl Acad Sci USA 77:649-652.

Khan T, Green B, Perez-Polo JR (1987) Effect of injury on nerve growth factor uptake by sensory ganglia. J Neurosci Res 18:562-567.

Larkfors L, Stromberg I, Ebendal T, Olson L (1987) Nerve growth factor protein level increases in the adult rat hippocampus after a specific cholinergic lesion. I Neurosci Res 18:525-531.

Lee VM-Y (1985) Neurofilament protein abnormalities in PC12 cells: comparison with neurofilament proteins of normal cultured rat sympathetic neurons. J Neurosci 5:3039-3046.

Lee VM-Y, Trojanowski JQ, Schlaepfer WW (1982) Induction of neurofilament triplet proteins in PC1 2 cells by nerve growth factor. Brain Res 238:169-180.

Leonard DGB, Ziff EB, Greene, LA (1987) Identification and characterization of mRNAs regulated by nerve growth factor in PC12 cells. Mol Cell Biol 7:3156-3167.

Levi-Montalcini R, Angeletti PU (1968) Nerve growth factor. Physiol Rev 48:534-569.

Lewis SA, Cowan NJ (1985) Genetics, evolution and expression of the 68,000 -mol-wt neurofilament protein: isolation of a cloned cDNA probe. J Cell Biol 100:843-850. 
Lieberman AR (1971) The axon reaction: a review of the principal features of perikaryal responses to axon injury. Int Rev Neurobiol $14: 49-124$.

Lindenbaum MH, Carbonetto S, Mushynski WE (1987) Nerve growth factor enhances the synthesis, phosphorylation, and metabolic stability of neurofilament proteins in PC12 cells. J Biol Chem 262:605610.

Lindenbaum MH, Carbonetto S, Grosveld F, Flavell D, Mushynski WE (1988) Transcriptional and posttranscriptional effects of nerve growth factor on expression of the three neurofilament subunits in PC1 2 cells. J. Biol Chem 263:5662-5667.

Lindsay RM, Harmar AJ (1989) Nerve growth factor regulates expression of neuropeptide genes in adult sensory neurons. Nature 337 362-364.

Milbrandt J (1987) A nerve growth factor-induced gene encodes a possible transcriptional regulatory factor. Science 238:797-799.

Miller MS, Buck SH, Sipes IG, Yamamura HI, Burks TF (1982) Regulation of substance $P$ by nerve growth factor: disruption by capsaicin. Brain Res 250:193-196.

Mobley WC, Schenker A, Shooter EM (1976) Characterization and isolation of proteolytically modified nerve growth factor. Biochemistry 15:5543-5552.

Nicoll RA, Schenker C, Leeman SE (1980) Substance P as a transmitter candidate. Annu Rev Neurosci 3:227-268.

Nielsch U, Keen $P$ (1988) Changes in tachykinin and actin gene expression in rat sensory neurones after cutting or crushing the sciatic nerve. Biochem Soc Trans 16:465-466.

Nielsch U, Bisby MA, Keen P (1987) Effect of cutting or crushing the rat sciatic nerve on synthesis of substance $P$ by isolated $L 5$ dorsal root ganglia. Neuropeptides (Edinburgh) 10:137-145.

Oblinger MM (1987) Characterization of posttranslational processing of the mammalian high molecular weight neurofilament protein in vivo. J Neurosci 7:2510-2521.

Oblinger MM, Lasek RJ (1985) Selective regulation of two axonal cytoskeletal networks in dorsal root ganglion cells. In: Neurobiology: molecular biological approaches to understanding neuronal function and development (O'Lague $P$, ed), pp 135-143. New York: Liss.

Oblinger MM, Lasek RJ (1988) Axotomy-induced alterations in the synthesis and transport of neurofilaments and microtubules in dorsal root ganglion cclls. J Neurosci 8:1747-1758.

Oblinger MM, Brady ST, McQuarrie IG, Lasek RJ (1987) Cytotypic differences in the protein composition of the axonally transported cytoskeleton in mammalian neurons. J Neurosci 7:453-462.

Oblinger MM, Szumlas RA, Wong J, Liuzzi FJ (1989) Changes in neurofilament gene expression affect the composition of regenerating axonal sprouts elaborated by DRG neurons in vivo. J Neurosci 9: $2645-2653$.

Otten U, Goedert M, Mayer N, Lembeck F (1980) Requirement of nerve growth factor for development of substance P-containing sensory neurons. Nature 287:158-159.
Otto D, Unsicker K, Grothe C (1987) Pharmacological effects of nerve growth factor and fibroblast growth factor applied to the transectioned sciatic nerve on neuron death in adult rat dorsal root ganglia. Neurosci Lett 83:156-160.

Richardson PM, Riopelle RJ (1984) Uptake of nerve growth factor along peripheral and spinal axons of primary sensory neurons. J Neurosci 4:1683-1689.

Richardson PM, Verge Issa VMK, Riopelle RJ (1986) Distribution of neuronal receptors for nerve growth factor in the rat. J Neurosci 6:2312-2321.

Ruit KG, Osborne PA, Schmidt RE, Johnson EM Jr, Snider WD (1990) Nerve growth factor regulates sympathetic ganglion cell morphology and survival in the adult mouse. J Neurosci 10:2412-2419.

Schwartz JP, Pearson J, Johnson EM Jr (1982) Effect of exposure to anti-NGF on sensory neurons of adult rats and guinea pigs. Brain Res 244:378-381.

Taniuchi M, Clark H, Schweitzer JB, Johnson EM Jr (1988) Expression of nerve growth factor receptors by Schwann cells of axotomized peripheral nerves: ultrastructural location, suppression by axonal contact, and binding properties. J Neurosci 8:664-681.

Thoenen H, Barde Y-A (1980) Physiology of nerve growth factor. Physiol Rev 60:1284-1335.

Traynor AE, Schubert D, Allen WR (1982) Alterations of lipid metabolism in response to nerve growth factor. J Neurochem 39:16771683.

Verge VMK, Tetzlaff W, Bisby MA, Richardson PM (1990) Influence of nerve growth factor on neurofilament gene expression in mature sensory neurons. J Neurosci 10:2018-2025.

Wilkin LD, Fagre LO, Jew JY, Williams TH (1983) The role of substance P-containing fibers in sympthetic ganglia: effect of capsaicin. Peptides 4:769-774.

Wong J, Oblinger MM (1987) Changes in neurofilament gene expression occur after axotomy of dorsal root ganglion neurons: an in situ hybridization study. Metab Brain Dis 2:291-303.

Wong J, Oblinger MM (1990a) A comparison of peripheral and central axotomy effects on neurofilament and tubulin gene expression in rat dorsal root ganglion neurons. J Neurosci 10:2215-2222.

Wong J, Oblinger MM (1990b) Differential regulation of peripherin and neurofilament gene expression in regenerating DRG neurons. $J$ Neurosci Res 27:332-341.

Yip HK, Johnson EM Jr (1984) Developing dorsal root ganglion neurons require trophic support from the central processes: evidence for a role of retrogradely transported nerve growth factor from the central nervous system to the periphery. Proc Natl Acad Sci USA 81:62456249.

Yip HK, Kich KM, Lampe PA, Johnson EM Jr (1984) The effects of nerve growth factor and its antiserum on the postnatal development and survival after injury of sensory neurons in rat dorsal root ganglia. J Neurosci 4:2986-2992. 